Акімова Л. М., к.е.н, доцент, доцент кафедри фінансів і економіки природокористування, Яркевич Г. В., студент (Національний університет водного господарства та природокористування, м. Рівне)

\title{
ЗАГАЛЬНА ХАРАКТЕРИСТИКА ПОДАТКОВИХ СИСТЕМ КРАЇН ПІВНІЧНОЇ ЄВРОПИ: ПЕРЕВАГИ ТА НЕДОЛІКИ
}

Стаття присвячена дослідженню загальних характеристик податкових систем країн Північної Європи. Встановлено ключові аспекти, які стосуються інтеграції нашої держави до Європейського Союзу, в частині гармонізації національної податкової системи з податковими системами країн ЄС. Розглянуто основні цілі та принципи податкової політики Європейського Союзу. Запропоновано основні напрями вдосконалення податкової політики України.

Ключові слова: податкова система, податки, країни Північної Європи, податок на додану вартість, корпоративний податок.

Актуальність проблеми дослідження. На сьогоднішній день актуальність обраної теми зумовлена тим, що в Україні проводиться робота щодо створення стабільного податкового законодавства, тому зарубіжний досвід розвинутих країн стане хорошим фундаментом для правильного формування податкового законодавства України.

Аналіз досліджень і публікацій. Проблематику даного питання досліджували вітчизняні та зарубіжні науковці, зокрема: І. Барановський, 3. Благун, 3. Варналій, О. Величко, Є. Волкова, І. Дмитренко, В. Загорський, А. Лаффер, Я. Литвиненко, О. Майстренко, О. Нідзельська, І. Прокопенко, А. Сміт, Т. Тучак, І Якушик та багато інших. Нестабільний стан податкової системи України обумовлює потребу в дослідженні зарубіжного досвіду, для виявлення переваг та недоліків системи оподаткування країн Північної Європи та формування податкового законодавства України.

Метою статті $\epsilon$ дослідження провідного зарубіжного досвіду регулювання соціально-економічного розвитку країни податковими методами та розробка пропозицій щодо його використання у вітчизняній практиці.

Виклад основного матеріалу. Внаслідок економічної експансії ЄС Україна отримала безпосередній доступ до єдиного, розширеного, гармонізованого ринку ЄС (далі - ЄС) з 450 мільйонами споживачів. Зважаючи на це, можна стверджувати, що Україна більшою мірою, 
ніж інші країни, зможе отримати свої дивіденди від доступу до єдиного ринку ЄС з високим рівнем відкритості, єдиним переліком торговельних правил і адміністративних процедур, єдиним митним тарифом та зі спрощеним рухом товарів, послуг, громадян і капіталу без усіляких бар'єрів [9].

Тому податкова система України має бути гармонізованою із закордонними податковими системами. Гармонізація податкових систем країн Європейського Союзу - це один з ключових елементів загального процесу фіскальної конвергенції, який виник з проблем податкової конкуренції. Інколи твердження про те, що податкова конвергенція, під якою розуміють процес зближення податкових систем країн з різним рівнем політичного й соціально-культурного розвитку, передбачає розробку і впровадження механізмів та інструментів фіскального регулювання на всіх наявних в інтеграційному угрупованні ієрархічних рівнях [11, С. 196]. Такий процес включає в себе стандартизацію систем, коінтеграцію інституцій і гармонізацію підходів до сталого соціально-економічного розвитку країн.

Таким чином, доцільно розглянути податкову політику Європейського Союзу. Вона являє собою систему заходів, які проводять органи та інститути ЄС. Мета податкової політики ЄС: гармонізація податкового законодавства, усунення податкових бар'єрів, неприпустимість недобросовісної податкової конкуренції, узгодження дій у боротьбі з податковим правопорушенням. Крім того, гармонізація податкового законодавства базується на основних принципах: пропорційності, субсидіарності, одноголосності, податкової недискримінації, нейтральності оподаткування.

Варто зазначити, що Європейська комісія не вважає, що повсюдна гармонізація податкових систем країн ЄС необхідна тією мірою, в якій створення і функціонування внутрішнього ринку не буде ускладнено. Країни повинні мати можливість обирати найбільш оптимальну для себе систему. Зусилля ЄС щодо гармонізації переважно зосереджені на законодавстві про податки, що стягуються з товарів і послуг.

Одним з головних елементів $є$ розмір податків, які сплачують як приватні особи, так і представники бізнесу. Валова частка країн Північної Європи входить до топ-5 країн Європи з найвищими податками. Детальніше розглянемо на прикладі діаграми рис. 1.

Податки у Фінляндії є досить високими. Фінляндія відрізняється високим рівнем життя, пристойними зарплатами і досить досконалою податковою системою. Розмір податкового внеску безпосередньо залежить від рівня отримуваної заробітної плати. У Фінляндії платити податки зобов'язані всі: як громадяни цієї країни, так і нере- 
зиденти. Основну частину скарбниці Фінляндії становлять саме податкові платежі з населення. У цій країні їх поділяють на такі категорії: непрямі та прямі.

Прямі податки містять:

- корпоративний податок;

- податок на дохід з капіталу;

- прибутковий податок;

- на майно.

Непрямі податки складають такі відрахування, як:

- на додану вартість;

- мито;

- податки на соціальні потреби;

- акцизний збір [7].

Ставки основних податків у Фінляндії в 2018 році становили: корпоративний податок на прибуток - 20\%; ПДВ: загальна ставка $24 \%$. Знижені ставки $14 \%$ (продукти харчування, послуги громадського харчування) і 10\% (книги, фармацевтична продукція, деякі види послуг).

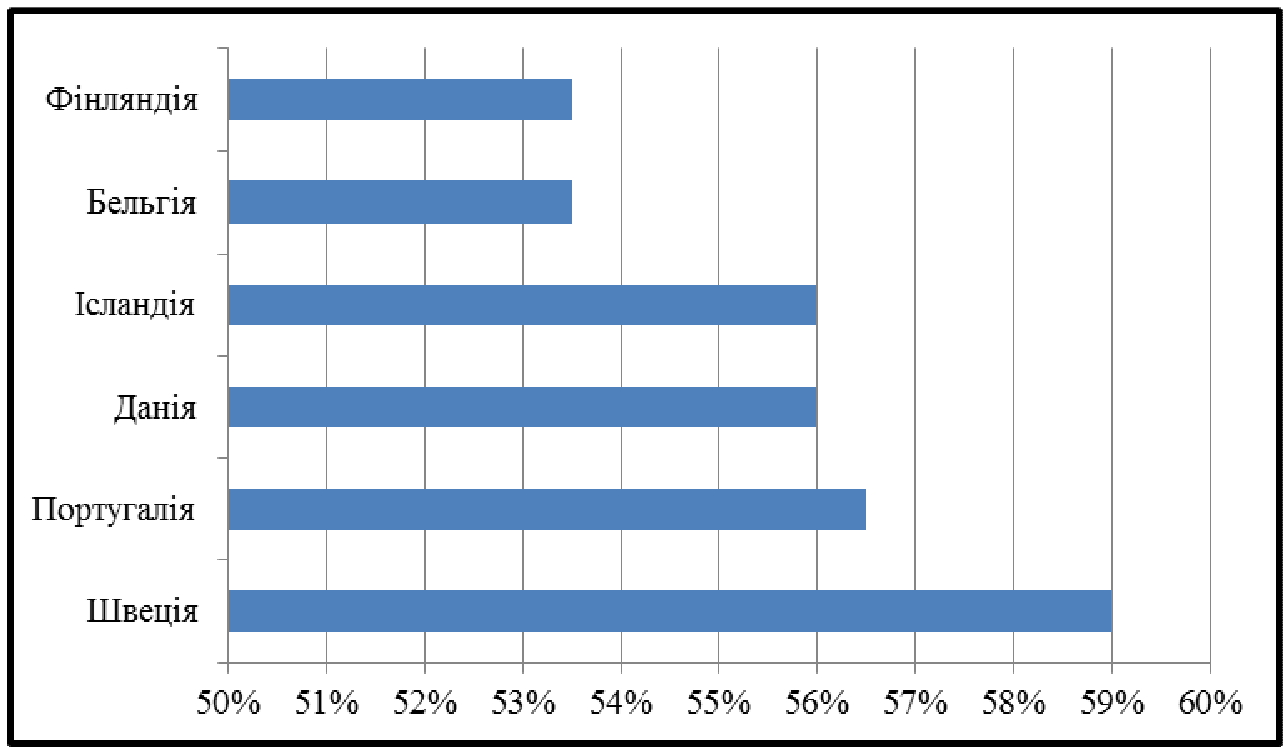

Джерело: складено автором

Рис. 1. Топ-5 країн Європи з найвищими податками

Крім того, в Фінляндії стягується податок з доходів акціонерів, приватних підприємців та командитних товариств. Доходи поділяються на трудові і капітальні. У першому випадку застосовується прогресивна ставка податку, чим вищий дохід тим більше ставка. 
Ставка податку на прибуток з капітальних доходів становить $30 \%$, якщо доходи не перевищують 30 тисяч євро; $34 \%$ - якщо доходи вище 30 тисяч євро. Прибутковий податок - прогресивна ставка в залежності від річного доходу: від 16,9 до 25,3 тисяч євро - 6,25\%; від 25,3 до 41,2 тисяч євро - 17,5\%; від 41,2 до 73,1 тисяч євро - 21,5\%; понад 73,1 тисяч євро - 31,5\%. Також у Фінляндії передбачені муніципальні податки 3 доходів за фіксованою ставкою 16-23\% (залежить від регіону) і церковний збір в розмірі 1-2\%.

На відміну від Фінляндії, Великобританія має розвинену податкову систему, яка сформувалася протягом багатьох століть. Податок на прибуток - фіскально й соціально найбільш важливий податок у Великобританії. Він передбачає низку пільг:

- неоподатковуваний мінімум складає 3445 фунтів стерлінгів на рік;

- для осіб старших 64 років - 4200 фунтів стерлінгів;

- для осіб старших 74 років - 4370 фунтів стерлінгів;

- неповним сім'ям, які мають дітей віком до 16 років;

- неповним сім'ям, діти яких навчаються у вищих навчальних закладах денної форми навчання;

- оподатковуваний дохід зменшується на суму витрат, пов'язаних з одержанням доходу (спецодяг, обладнання для роботи), а також на суми внесків до пенсійних і благодійних фондів, медичної страховки для старших 65 років, процентних платежів по позиках на придбання житла та власності (максимум 30 тис. фунтів стерлінгів).

Величина знижок щорічно індексується в залежності від рівня інфляції. До цього ж у Великобританії існує дещо інший принцип (на відміну від інших кран Європи) побудови та нарахування податку на прибуток, який розподіляє дохід на певні групи (шедули) в залежності від джерела отриманого доходу. Діє всього 5 груп, кожна така група оподатковується за особливим принципом і названа в порядку англійського алфавіту: A, C, D, E, F.

Ставки основних податків у Великобританії в 2018 році становила: корпоративний податок - 19\%; прибутковий податок - прогресивна ставка від 0\% до 45\%; ПдВ - основна ставка - 20\%, знижені - 5\% (побутова електроенергія, дитячі коляски, допоміжні засоби для пересування інвалідів) і 0\% (книги, дитячий одяг, продукти харчування).

Зазначимо, що однією з особливостей британської податкової системи $є$ відрахування частини прибутку до фонду національного страхування. Спочатку за рахунок цих коштів планувалося збільшити різноманітні державні допомоги, пенсії та інші соціальні виплати. Насправді це просто додатковий податок. Ставки тут в залежності від 
прибутку:

- прибуток менше 8060 фунтів - ставка 2,8 фунта на тиждень;

- прибуток від 8060 до 42385 фунтів - ставка 9\%;

- прибуток понад 42385 фунтів - ставка 2\%.

Зазначимо, що податкове регулювання одна із основних інструментів управління економікою багатьох країн. 3 допомогою зміни ставок держава має впливати на становище ринку виробництва і економіки загалом. Що ж до Данії - податкова система цієї країни є цілісним механізмом, що функціонує практично без збоїв. Основною функцією податкової системи є перерозподіл сукупного доходу між резидентами країни. 3 іншого боку податки у Данії зумовлюють ефективність для економіки в цілому. Данія - досить розвинена країна. У цій країні дуже добре розвинене сільське господарство, машинобудування. Успішно конкурує Данія ще й над ринком високих технологій. Попри обмеженість ресурсів орієнтується на зовнішню торгівлю і імпорт. Країна займає сьоме місце по розрахунках ВВП на душу населення.

У Данії досить сприятливий податковий клімат, зокрема, ставка корпоративного податку $22 \%$, одна з найбільш прийнятних в Європі. Соціальні внески мінімальні, а деякі іноземні наймані працівники перші 5 років платять прибутковий податок в меншому розмірі. 3 більшістю країн світу Данією підписані угоди про уникнення подвійного оподаткування. В Данії не можна сказати, що низькі податкові ставки, це не так. Ставки основних податків Данії в 2018 році становили: корпоративний податок на прибуток - 22\%; ПДВ - 25\% і пільгова ставка 0\% (газети, журнали); дивіденди - 25\% для компаній, а також $27 \%$ для фізичних осіб, якщо сума не перевищує 50,6 тисяч датських крон і 42\% у разі перевищення; прибутковий податок - прогресивна ставка досягає 56,48\%.

У Данії дуже важливу роль відіграє держава. В першу чергу держава $є$ основним одержувачем податкових надходжень, а також перерозподіляє сукупний дохід через бюджетно-податкову систему. Держава є як соціальним, так і економічним гарантом для населення. Виходячи з вище сказаного ми можемо проаналізувати ставки корпоративного податку за 2018 рік у країнах Північної Європи за допомогою діаграми на рис. 2. 


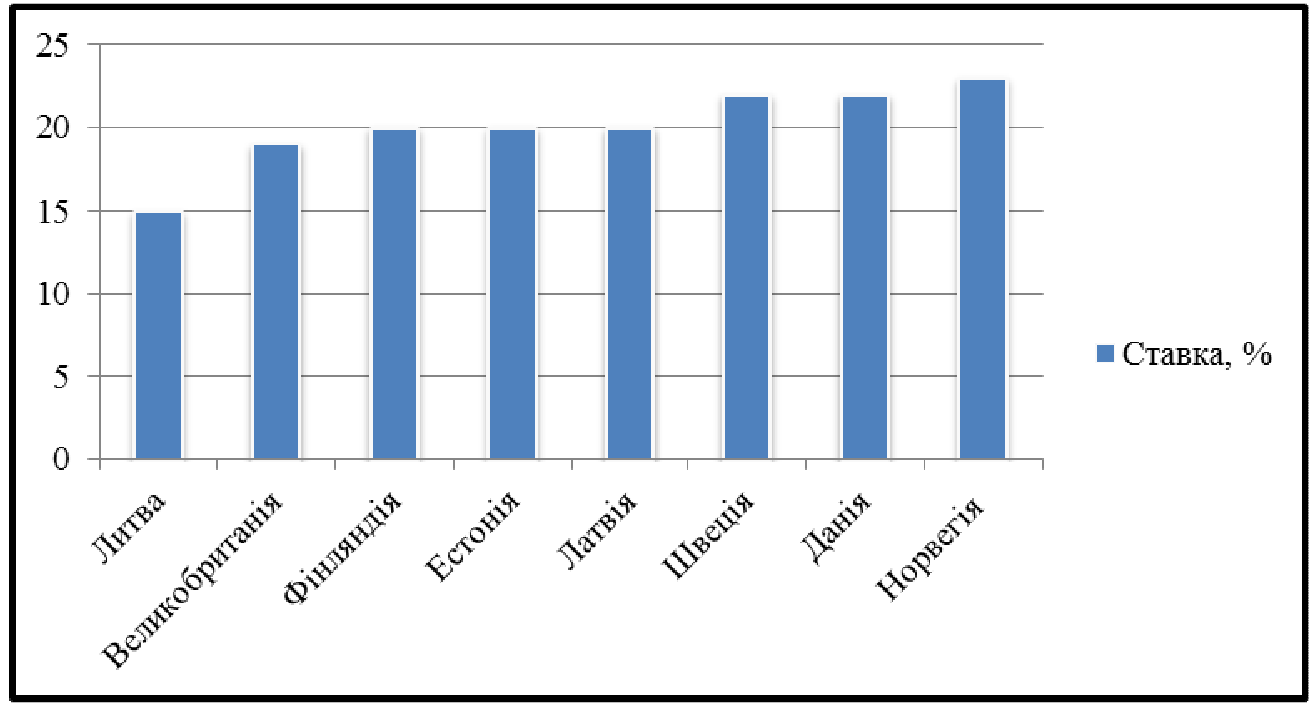

Рис. 2. Корпоративний податок у країнах Північної Європи у 2018 році [10]

Проаналізувавши динаміку, ми бачимо, що найнижча ставка корпоративного податку у Литві, вона становить 15\%, а найвища у Норвегії - 23\%. Фінляндія, Естонія та Латвія мають ставку корпоративного податку - $20 \%$.

Крім того, на рис. 3 досліджено розмір ставки ПДВ за 2018 рік у країнах Північної Європи.

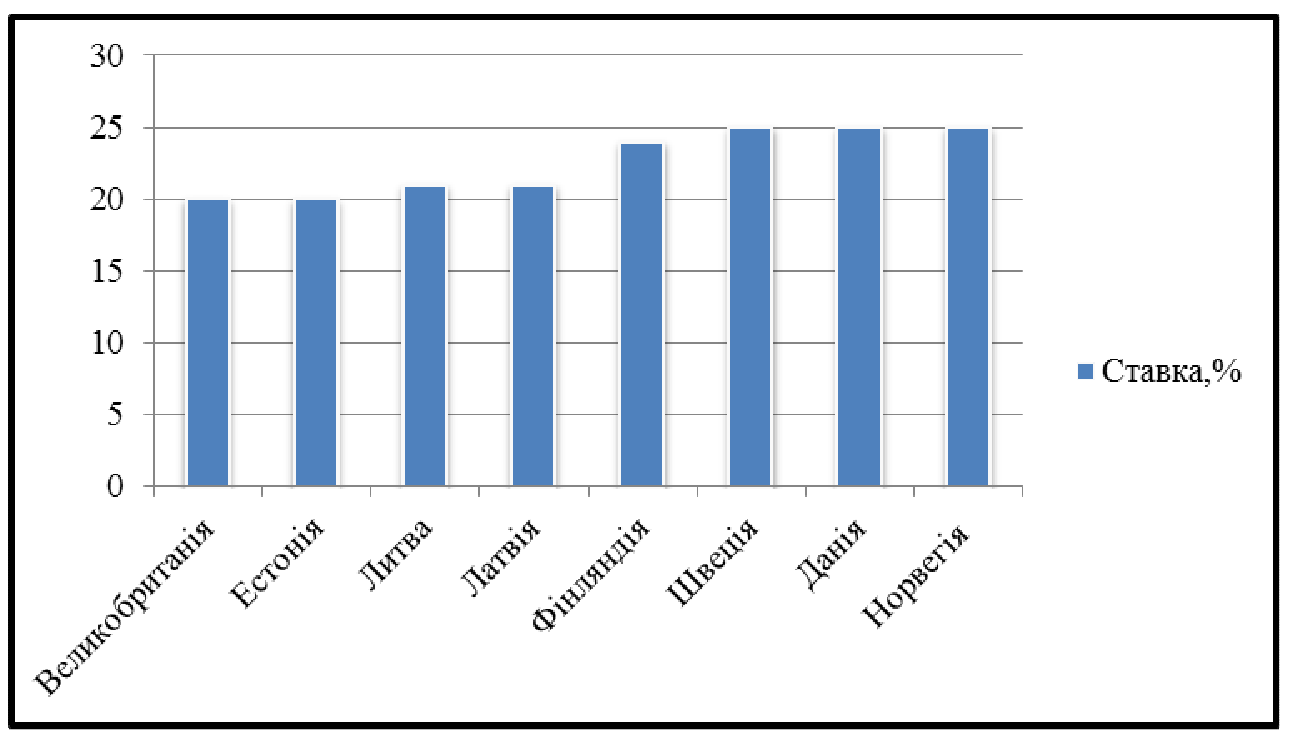

Рис. 3. Ставка ПДВ у 2018 році в країнах Північної Європи [10]

Отже, проаналізувавши динаміку, ми можемо зробити висновки, що ставки ПДВ коливаються від 20\% до 25\%. Великобританія та 
Естонія мають найнижчу ставку - 20\%, а Норвегія, Данія, Швеція найвищу ставку $25 \%$.

Залежно від ступеня оподаткування прибутку підприємств науковці В.М. Гриньова, М.М. Новікова [3] пропонують поділяти країни світу на 4 основні групи. Але враховуючи результати досліджень вчених та вищезазначених зарубіжних систем оподаткування країн згрупуємо країни світу таким чином:

- країни $з$ класичною системою подвійного оподаткування (існує подвійне оподаткування прибутку: того, що реінвестується та того, який виплачується власникам капіталу (Україна, США, Бельгія, Нідерланди, Люксембург, Швеція));

- країни в яких прибуток підприємств повністю звільнений від оподаткування (Греція, Норвегія);

- країни в яких від оподаткування звільнено прибуток який виплачується акціонерам (Австралія, Нова Зеландія, Італія, Фінляндія);

- країни в яких прибуток отриманий акціонерами на рівні компаній оподатковується за більш низькою ставкою податку (Австрія, Німеччина, Португалія, Японія) або частково звільняється від оподаткування (Іспанія, Ісландія);

- країни в яких оподаткування прибутку знижується на рівні акціонерів: вони звільняються від оподаткування доходу отриманого у вигляді дивідендів (Данія, Канада, Японія) або податок, який сплачує компанія з прибутку, розподіляється частково, тобто податковий кредит (Великобританія, Ірландія, Франція).

Зазначимо, що світовий банк опублікував щорічний рейтинг Doing Business, який визначає діловий клімат в тій чи іншій країні, виходячи з таких критеріїв, як легкість відкриття нового бізнесу, отримання дозволу на будівництво, простота оподаткування, реєстрація власності, отримання позик, захист прав інвесторів. У рамках дослідження збирається та аналізується інформація для зіставлення умов регулювання підприємницької діяльності в різних країнах, що дозволяє не тільки вказати на ті проблеми, які погіршують умови ведення бізнесу, але і виробити певні рекомендації для проведення необхідних реформ. Одним з найбільш цікавих $є$ рейтинг країн за блоком Paying taxes, який складається Світовим банком у співпраці 3 PricewaterhouseCooper's для оцінки якості системи оподаткування для бізнесу. Цим рейтингом оцінюється податкове навантаження середньостатистичного підприємства у розділі адміністрування та сплати корпоративного податку, соціальних відрахувань, податків, що утримуються з доходів працівників, податків на майно, податків на передавання права власності, податків 3 дивідендів та інших 
обов'язкових платежів.

До однієї з найбільш вдалих та показових податкових реформ ЄС належить впровадження нової системи оподаткування малого бізнесу в Німеччині. У 2014 р. уряд ФРН ухвалив законопроект, згідно з яким представники малого бізнесу можуть отримати податкові канікули на термін до 3 років за умови прибутковості в останні 3 фінансових роки. Крім того, малий бізнес в Німеччині тепер має пріоритетне право на обслуговування державних закупівель у відношенні до великих корпорацій [1].

Враховуючи проведений аналіз, можна сформувати певні переваги оподаткування ЄС, а саме:

- ліберальне податкове законодавство для малого бізнесу у більшості країн;

- наявність податкових пільг та знижок за умови прибутковості;

- адаптивне звільнення від оподаткування новостворених підприємств строком до 6 місяців;

- велика кількість вільних економічних зон;

- спрощена процедура відносин з податковими органами - абсолютно весь документооборот проходить в електронному режимі [6; 2].

Крім того, слід зауважити, що оподаткування в Євросоюзі має і певні недоліки, які можна виокремити таким чином:

- велика кількість малих підприємств, обробляти які необхідно відповідно до закріплених за регіоном податкових органів, призводить до зростання державних видатків на утримання апарату;

- дещо дискримінаційна політика щодо великих корпорацій;

- великий обсяг навантаження непрямими податками у відношенні до прямих;

- наявність офшорних зон, які використовуються для відмивання грошових потоків і легалізації незаконних прибутків [4; 5].

Слід зауважити, що впровадження податкових реформ Європейського Союзу в Україні $€$ першочерговим завданням на шляху економічного розвитку. Стимулююча політика податкової системи сприятиме розвитку підприємництва та зростанню доходів держави. Основними напрямами мають бути:

- зменшення податкового тиску;

- вирівнювання нерівномірності розподілу податків;

- подальше зменшення податків та платежів;

- концентрація на використанні інноваційних методів адміністрування;

- модернізація податкових інструментів стимулювання підприємництва; 
- створення і розвиток податкової культури;

- розробка стратегії розвитку малого підприємництва з урахуванням податкових реформ;

- збільшення відповідальності за ухилення від податків, створення повноцінної контролюючої структури з незалежними керівниками [8].

На підставі вивчення зарубіжного досвіду можливо визначити ключові принципи, яких слід дотримуватися в ході реформування вітчизняної системи оподаткування:

- сприяння розвитку вітчизняного товаровиробника;

- забезпечення дотримання принципу соціальної справедливоCTi;

- створення сприятливих умов для залучення іноземного інвестиційного капіталу.

Висновки. Підсумовуючи викладений матеріал слід зазначити, що вивчення досвіду податкового регулювання економіки у провідних Європейських країнах з ринковою економікою, дозволило визначити особливості їх податкових систем, які можна і потрібно переймати Україні. Слід зазначити, що система ДФС України на сьогоднішній день працює досить ефективно. Але сучасний розвиток світової економіки вимагає постійного їі розвитку та вдосконалення, для цього необхідно швидко реагувати на зміни, яких вимагає час, адже від ефективності дій цієї системи залежить добробут держави [9]. Визначені переваги та недоліки системи оподаткування ЄС повинні служити керівництвом до дії для українських реформаторів, яким необхідно примножити позитивний ефект від таких реформ і нівелювати негативний.

1. European Commission «Taxation trends in the European Union - Data for the EU Member States, Iceland and Norway» Luxembourg: Publications Office of the European Union, 2014. 308 pp. URL: http://ec.europa.eu/eurostat/documents/3217494/5786841/KS-DU-14-001EN. PDF/7bec4a16-f111-4386-a4b4-8f1087be1063?version=1.0 (дата звернення: 15.01.2019). 2. Біла Л. М. Спільні і відмітні риси податкових систем країн європейського союзу та України. Глобальні та національні проблеми економіки. 2015. № 6. С. 656-661. 3. Гриньова В. М., Новікова М. М. Державне регулювання економіки. Харків : ВД «ІНЖЕК», 2004. 756 с. 4. Канкава О. А. Реформи податкової системи України в контексті євроінтеграції. Вісник КНЕУ. 2016. № 8. С. 251-256. 5. Леоненко В. О. Перспективи та недоліки впровадження реформ європейської податкової системи в Україні. Вісник ХНУ. 2016. № 11. С. 28-32. 6. Максименко А. В. Податкові реформи та перспективи оподаткування: світова панорама. Економічний аналіз : зб. наук. праць. 2016. Т. 24. № 1. С. 51-56. 7. Манжула А. Етапи розвитку системи 
державної податкової служби України. Підприємництво, господарство і право. 2004. № 11. С. 85-88. 8. Нагорняк Г., Вовк Ю. Проблеми податкового регулювання в Україні та шляхи їх вирішення. Галицький економічний вісник. 2010. № 2 (27). С. 140-152. 9. Офіційний сайт Фіскальної служби України. URL: http://sfs.gov.ua/ (дата звернення: 15.01.2019). 10. Сайт Migranty. URL: https://migranty.com/news/856 (дата звернення: 15.01.2019). 11. Юрченко В. В. Сучасні тенденції розвитку та гармонізації податкових систем країн Європейського Союзу. Вектори для України. Ефективна економіка : електронне наукове фахове видання. 2013. № 12.

\section{REFERENCES:}

1. European Commission «Taxation trends in the European Union - Data for the EU Member States, Iceland and Norway» Luxembourg: Publications Office of the European Union, 2014. 308 pp. URL: http://ec.europa.eu/eurostat/documents/3217494/5786841/KS-DU-14-001EN. PDF/7bec4a16-f111-4386-a4b4-8f1087be1063?version=1.0 (data zvernennia: 15.01.2019). 2. Bila L. M. Spilni i vidmitni rysy podatkovykh system krain yevropeiskoho soiuzu ta Ukrainy. Hlobalni ta natsionalni problemy ekonomiky. 2015. № 6. S. 656-661. 3. Hrynova V. M., Novikova M. M. Derzhavne rehuliuvannia ekonomiky. Kharkiv : VD «INZhEK», 2004.756 s. 4. Kankava 0 . A. Reformy podatkovoi systemy Ukrainy $v$ konteksti yevrointehratsii. Visnyk KNEU. 2016. № 8. S. 251-256. 5. Leonenko V. O. Perspektyvy ta nedoliky vprovadzhennia reform yevropeiskoi podatkovoi systemy $v$ Ukraini. Visnyk KhNU. 2016. № 11. S. 28-32. 6. Maksymenko A. V. Podatkovi reformy ta perspektyvy opodatkuvannia: svitova panorama. Ekonomichnyi analiz : zb. nauk. prats. 2016. T. 24. № 1. S. 51-56. 7. Manzhula A. Etapy rozvytku systemy derzhavnoi podatkovoi sluzhby Ukrainy. Pidpryiemnytstvo, hospodarstvo i pravo. 2004. № 11. C. 85-88. 8. Nahorniak H., Vovk Yu. Problemy podatkovoho rehuliuvannia $v$ Ukraini ta shliakhy yikh vyrishennia. Halytskyi ekonomichnyi visnyk. 2010. № 2 (27). S. 140-152. 9. Ofitsiinyi sait Fiskalnoi sluzhby Ukrainy. URL: http://sfs.gov.ua/ (data zvernennia: 15.01.2019). 10. Sait Migranty. URL: https://migranty.com/news/856 (data zvernennia: 15.01.2019). 11. Yurchenko V. V. Suchasni tendentsii rozvytku ta harmonizatsii podatkovykh system krain Yevropeiskoho Soiuzu. Vektory dlia Ukrainy. Efektyvna ekonomika : elektronne naukove fakhove vydannia. 2013. № 12.

Akimova L. M., Candidate of Economics (Ph.D.), Associate Professor, Department of Finance and Economics of Environmental Management, Yarkevych H. V., Senior Student (National University of Water and Environmental Engineering, Rivne) 


\section{GENERAL CHARACTERISTICS OF THE TAX SYSTEMS OF NORTH EUROPE COUNTRIES: ADVANTAGES AND DISADVANTAGES}

The article is devoted to the study of the general characteristics of the tax systems of the countries of Northern Europe. The key aspects concerning the integration of our country into the European Union have been identified in the part of the harmonization of the national tax system with the tax systems of EU countries. The main goals and principles of the tax policy of the European Union are considered. The basic directions of improvement of the tax policy of Ukraine are offered.

Keywords: tax system, taxes, Northern European countries, value added tax, corporate tax.

Акимова Л. Н., к.э.н, доцент, доцент кафедры финансов и экономики природопользования, Яркевич Г. В., студент (Национальный университет водного хозяйства и природопользования, г. Ровно)

ОБЩАЯ ХАРАКТЕРИСТИКА НАЛОГОВЫХ СИСТЕМ СТРАН СЕВЕРНОЙ ЕВРОПЫ: ПРЕИМУЩЕСТВА И НЕДОСТАТКИ

Статья посвящена исследованию общих характеристик налоговых систем стран Северной Европы. Установлено ключевые аспекты, которые касаются интеграции нашего государства в Европейский Союз, в части гармонизации национальной налоговой системы с налоговыми системами стран ЕС. Рассмотрены основные цели и принципы налоговой политики Европейского Союза. Предложены основные направления совершенствования налоговой политики Украины.

Ключевые слова: Налоговая система, налоги, страны Северной Европы, налог на добавленную стоимость, корпоративный налог. 